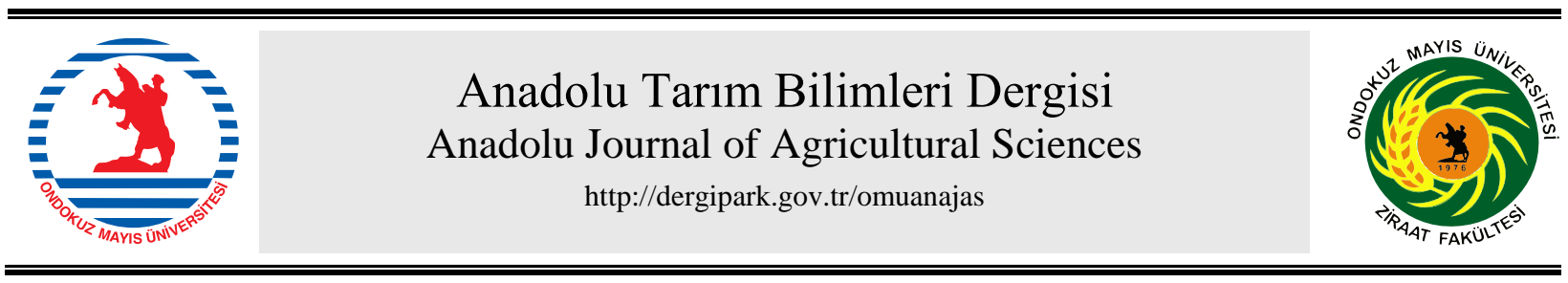

Araştırma/Research

Anadolu Tarım Bilim. Derg./Anadolu J Agr Sci, 35 (2020) ISSN: 1308-8750 (Print) 1308-8769 (Online) doi: 10.7161/omuanajas.743199

\title{
Döl Kontrolü Parsellerindeki Yonca (Medicago sativa L.) Genotiplerinin Verim ve Kalite Özellikleri ile Genel Kombinasyon Yeteneklerinin Belirlenmesi
}

\author{
Sebahattin Albayrak*a, ๑Mehmet Öten ${ }^{\mathrm{b}}$ \\ ${ }^{a}$ Ondokuz Mayls Üniversitesi, Bafra Meslek Yüksekokulu, Samsun, Turkey \\ ${ }^{b}$ Batı Akdeniz Tarımsal Araştırma Enstitüsü, Antalya, Turkey
}

*Sorumlu yazar/corresponding author: sebahattinalbayrak@omu.edu.tr

Geliş/Received 27/05/2020＜noBreak>＜noBreak>Kabul/Accepted 17/06/2020

\section{ÖZET}

$\mathrm{Bu}$ çalışmanın amacı döl kontrolü parsellerinde yer alan yonca (Medicago sativa L.) genotiplerinin verim ve kalite özellikleri ile genel kombinasyon yeteneklerini belirlemektir. 10 adet seçilmiş yonca genotipi 2016 ve 2017 yılları arasında iki yıl boyunca Isparta koşullarında denenmiştir. Çalışma Tesadüf Blokları Deneme Desenine göre 4 tekrarlamalı olarak kurulmuştur. Çalışmada tesis yılı hariç (2015 y1l1) vejetasyon peryodu boyunca her y1l 5 biçim yapılmıştır. İncelenen tüm özelliklerin ortalama değerleri aşağıdaki gibi bulunmuştur: Yeşil ot verimi $9239 \mathrm{~kg} \mathrm{da}^{-1}$, kuru ot verimi $2321.15 \mathrm{~kg} \mathrm{da}^{-1}$, ham protein oran $1 \% 20.69$, ADF oran1 \%29.69, NDF oran1 \%39.54, nispi yem değeri \%155.32. Genotiplerin ot verim ve kalite değerleri yanı sıra genel kombinasyon yetenekleri de göz önünde bulundurulduğunda yeni bir çeşit geliştirmek için 7 adet genotip (Eğirdir-2, Yalvaç-3, Bolvadin-1, Yeşilova-3, Beyşehir-2, Senirkent-2 ve Çay-1) Sentetik-0’1 oluşturmak amacıyla seçilmişlerdir.

Determination of Yield and Quality Characteristics with General Combination Abilities of Alfalfa (Medicago sativa L.) Genotypes in Progeny Control Plots

\section{ABSTRACT}

This study was conducted to analyze the differences in the Information and Communication Technologies (ICT) between the population living in rural and urban areas in Ankara. The study is particularly important as it is an original research that lays down the groundwork for developing potential future ICT strategies for rural development by determining the difference in ICT usage between rural and urban populations. In the study 50 men and women each living in rural areas were surveyed as well as an additional 50 men and women each living in urban areas by using a customdeveloped multiple-choice survey through purposeful sampling. Data collected were analyzed with SPSS statistical analysis software for both personal and gender factors. Khi-squire $\left(\chi^{2}\right)$ analyses were made to reveal the differences between variables. The results showed that there were significant differences between gender and location (rural vs. urban) in terms of education, income and employment in addition to preferred ICT tools and the use cases. Evaluation of the results revealed that the women living in rural areas utilize ICT less than those who live in urban areas and also increasing ICT security in rural-specific ways would make a significant difference.
Anahtar Sözcükler:

Döl kontrolü

Genel kombinasyon

Kalite

Verim

Yonca

Keywords:

Alfalfa

General combination

Progeny

Quality

Yield

(c) OMU ANAJAS 2020 


\section{Giriş}

Coğrafya ve iklim bakımından çok elverişli konumda bulunan Türkiye, bitki çeşitliliği bakımından oldukça zengindir. Ülkemiz, kültüre alınmış pek çok bitki türünün gen kaynağını oluşturmakta fakat bu potansiyelini yeterince değerlendirememektedir. Tarımsal üretimini ve ihracatını artıramamasına karşılık, tarımsal ithalat rakamları daha da artış göstermektedir. Gıda güvencesinin ve diş ticaret dengesinin ihracat yönünde sağlanabilmesi için üretim maliyetlerinin düşürülmesi ve destekleme araçlarının doğru ve amaca uygun olarak kullanılması gerekmektedir (Albayrak ve ark., 2018).

Tarım ve Ormancılık Bakanlığı'nın 2019 yılında açıkladığ 1 verilerine göre Türkiye'de yem bitkileri ekim alanları; yonca; 693.795 ha, korunga; 194.976 ha, fiğ 482.253 ha, misır; 1.073 .598 ha; diğer; 163.575 ha olmak üzere toplam 2.608.197 ha'dır. Toplam yem bitkileri üretimi sap, saman ve anız hariç 52.000 .000 tondur. Toplam kaliteli kaba yem ihtiyac1 ise 67.000.000 ton olarak hesaplanırken yem açı̆̆ 15.000.000 ton olduğu bildirilmiştir. Dolayısıyla mevcut hayvanların ihtiyaç duyduğu kaliteli kaba yemin yetersiz olduğunu söyleyebiliriz.

Türkiye'de yem bitkileri ekim alanın artırılması ve kaliteli kaba yem ihtiyacının giderilebilmesi için kullanılabilecek bitkilerin en başında yonca gelmektedir. Yonca (Medicago sativa L.) çok yıllık baklagil yem bitkisidir. Yüksek yem kalitesi ve hemen her bölge koşullarına uyum yeteneği sayesinde, Dünya'da en önemli yem bitkilerinin başında gelmektedir. Dünya'da 80 den fazla ülkede yetiştiriciliği yapılan yonca yaklaşı 35 milyon hektar alanda ekimi yapilmakta ve 440 milyon ton civarında bir üretim değerine ulaştığı bildirilmektedir (Radoviç ve ark., 2009).

Yoncada yeni bir çeşit geliştirmedeki başarı uygulanacak 1slah yöntemine bağlıdır (Katiç ve ark., 2008). Yonca gibi yabancı tozlaşan bitkilerde sentetik çeșitlerin geliştirilmesi dolaysıyla sentetik varyete ıslahı programının uygulanması yaygindır (Poelman ve Stabeck, 1995). Sentetik çeşit oluştururken de ebeveynleri seçilmesinde en etkili yöntemin döl kontrolü testlerinin yapılması gerekliliğidir (Miliç ve ark., 2011). Döl kontrolü testleri, yoncaların heterotik ebeveyn popülasyonlarının seçiminde önemli bir rol oynadı $\breve{g}_{1}$ bildirilmektedir (Riday ve Brummer, 2002).

$\mathrm{Bu}$ çalışmanın amacı döl kontrolü parsellerinde yer alan yonca genotiplerinin verim ve kalite özelliklerini inceleyerek sentetik-0'1 oluşturmak amacıyla seçilecek olan genotiplerin genel kombinasyon yeteneklerini belirlemektir.

\section{Materyal ve Yöntem}

$\mathrm{Bu}$ araștırma, 2015-2017 yılları arasında Isparta koşullarında, Süleyman Demirel Üniversitesi Araştırma ve Uygulama Çiftliği arazisinde yer alan araştırma parsellerinde yürütülmüştür. Deneme yeri $37^{\circ} 45^{\prime}$ Kuzey enlem ve 30 33' Doğu boylamında olup, denizden yükssekliği 1035 m'dir. Deneme alanı toprağının tınlı, hafif alkali, elverişli fosfor ve potasyum yönünden zengin, organik madde bakımından ise fakir olduğu görülmektedir. Denemenin yürütüldüğü yıllara ait iklim verileri ise Çizelge 1'de verilmiştir.

Çizelge 1. Denemenin yürütüldüğü Isparta iline ait iklim verileri

Table 1. Climate data of Isparta province where the research was conducted

\begin{tabular}{lccccccccc}
\hline \multirow{2}{*}{ Aylar } & \multicolumn{3}{c}{ Yağıș $\mathbf{( m m )}$} & \multicolumn{3}{c}{ Sıcaklı $\left({ }^{\circ} \mathbf{C}\right)$} & \multicolumn{3}{c}{ Nem (\%) } \\
\cline { 2 - 10 } Ocak & Uzun yıllar & $\mathbf{2 0 1 6}$ & $\mathbf{2 0 1 7}$ & Uzun yıllar & $\mathbf{2 0 1 6}$ & $\mathbf{2 0 1 7}$ & Uzun yıllar & $\mathbf{2 0 1 6}$ & $\mathbf{2 0 1 7}$ \\
Şubat & 80.6 & 101.6 & 87.8 & 1.8 & 1.3 & 0.8 & 75.2 & 71.9 & 77.9 \\
Mart & 68.8 & 33.3 & 3.6 & 2.9 & 7.3 & 3.0 & 71.6 & 69.4 & 68.5 \\
Nisan & 58.9 & 59.9 & 74.4 & 5.9 & 7.6 & 7.3 & 66.0 & 62.1 & 64.1 \\
Mayıs & 53.2 & 47.8 & 25.6 & 10.7 & 14.0 & 10.6 & 61.5 & 52.3 & 59.6 \\
Haziran & 55.7 & 8.76 & 149.5 & 15.5 & 14.6 & 14.9 & 59.2 & 64.4 & 63.7 \\
Temmuz & 33.2 & 12.4 & 30.9 & 20.0 & 21.6 & 20.1 & 52.5 & 48.2 & 58.9 \\
Ağustos & 13.7 & 25.7 & 13.1 & 23.4 & 25.0 & 25.2 & 45.7 & 44.1 & 41.6 \\
Eylül & 12.1 & 45.4 & 20.4 & 23.2 & 24.4 & 23.8 & 46.4 & 51.8 & 52.1 \\
Ekim & 18.6 & 31.6 & 5.7 & 18.6 & 18.9 & 21.1 & 52.3 & 53.9 & 45.1 \\
Kasım & 37.7 & 1.6 & 46.5 & 13.0 & 14.8 & 13.1 & 62.4 & 57.7 & 61.8 \\
Aralık & 45.2 & 48.8 & 41.7 & 7.6 & 7.2 & 6.7 & 70.0 & 64.7 & 74.3 \\
Toplam & 87.1 & 33.5 & 31.2 & 3.5 & 0.3 & 5.0 & 75.8 & 69.5 & 76.6 \\
Ortalama & $\mathbf{5 6 4 . 8}$ & $\mathbf{5 9 . 2}$ & $\mathbf{5 3 0 . 4}$ & - & - & - & - & - & - \\
\hline
\end{tabular}


Araştırma materyali olan yonca (Medicago sativa L.), 2010 y1lında TUBITAK-110O257 projesi kapsamında; Göller yöresinde yer alan toplam 4 ile ait 22 ilçeden 60 farklı duraktan klon olarak toplanmıştır. Fenolojik, morfolojik, verim ve kalite bakımından üstün özellik gösteren ayrıca moleküler karakterizasyon bakımından da farklılık arz eden 10 adet genotip sentetik varyete islahında kullanılmak üzere seçilmiştir. Seçilen Eğirdir-2, Yalvaç-3, Bolvadin-1, Senirkent-2, Yeşilova-3, Beyşehir-2, Çay-1, Sultandağı-2, Şarkikaraağaç-3 ve Yenişarbademli-1 yonca genotipleri çoklu melez (polycross) parsellerinde, 10x10 latis deneme deseniyle, 4 tekrarlamalı olarak klon halinde tesis edilmiştir. Çoklu melez parsellerinde yer alan her bir genotipin tohumları ayrı ayrı hasat edilmiştir. Elde edilen tohumlarla döl kontrolü parselleri tesis edilmiştir (Albayrak ve ark., 2014).

Döl kontrolü amacıyla; 26 Mart 2015 tarihinde, 10 adet yonca genotipi, tesadüf blokları demene desenine göre, 4 tekrarlamalı olarak, dekara $2 \mathrm{~kg}$ tohum hesabiyla ekimleri gerçekleştirilmiştir. Ekimle birlikte $3 \mathrm{~kg} \mathrm{da}^{-1}$ saf azot ve $8 \mathrm{~kg} \mathrm{da}^{-1}$ saf fosfor gübresi uygulanmıştır. Denemede, parsel uzunluğu $5 \mathrm{~m}$, sira arası $20 \mathrm{~cm}$, parsel sıra sayısı ise 8 adettir. Araştırmanın ilk yılında yonca bitkisinin çok yıllık olması nedeniyle herhangi bir gözlem ve ölçüm yapılmamış ancak ilk yıl sadece bakım işlemleri uygulanmış olup, diğer tüm veriler çalışmanın ikinci ve üçüncü yıllarında alınmıştır. Hasat, yoncada $\% 10$ çiçeklenme döneminde olmak üzere her iki yılda toplam 5'er biçim (hasat tarihleri: 28 Mayıs, 30 Haziran, 29 Temmuz, 28 Ağustos ve 28 Eylül 2016; 25 Mayıs, 28 Haziran, 27 Temmuz, 29 Ağustos ve 3 Ekim 2017) yapılmıştır. Her biçim sonrası toprak tarla kapasitesine gelinceye kadar ilk üç biçimden sonra 2 defa dördüncü biçimden sonra ise 1 defa sulama yapılmıştır.

Araştırmada; her parselin kenarlarından birer sıra, üst ve alt kısmından $0.5 \mathrm{~m}$ biçilerek parselden uzaklaştırılmış ve geriye kalan alan biçilerek hasat edilen her parselden elde edilen yeşil ot tartılmış ve elde edilen değerler dekara çevrilerek bulunmuştur. Her parselden biçilen yeşil ot kümesinden rastgele alınan yaklaşık 500 g'lık taze ot örnekleri, kurutma dolabında 48 saat $70^{\circ} \mathrm{C}^{\prime}$ de kurutularak 24 saat oda rutubetinde bekletildikten sonra $2 \mathrm{~g}$ duyarlı terazide tartılarak kuru ot ağırlıkları ulunmuştur. Her parselden elde edilen kuru ot oranları parsellerden elde edilen yeşil ot verimleri ile çarpılarak dekara kuru ot verimi hesaplanmıştır (Albayrak ve ark., 2018).

Ham protein için öğütülmüş her örnekten $1 \mathrm{~g}$ tartılıp, önceden hazırlanan çözeltiler yardımıyla Kjeldahl yöntemi uygulanarak ham protein oranları \% olarak belirlenmiştir (Kacar ve İnal, 2008). ADF ve NDF analizleri ANKOM 220 Fiber Analyser cihazı yardımıyla ANKOM teknolojinin bildirdiği esaslara göre yapılmıştır (Anonim, 2017). Nispi yem değerleri (Albayrak ve ark. 2018)'nn belirledikleri denkleme göre hesaplanmıştır. $\quad \mathrm{NYD}=[120 / \mathrm{NDF}] \times[88.9-(0.779$ $\times \mathrm{ADF})] \times[0.775]$.

Denemelerin sonuçları, Tesadüf Blokları Deneme Deseni'ne göre varyans analizlerine tabi tutularak (SAS, 1998) paket programında analizler yapılmıştır. Ayrıca, yıl birleştirmesinde Çınar ve ark. (2014) tarafından açıklanan Tesadüf Bloklarında Zamanda Bölünmüş Parseller Deneme Desenine uygun olarak varyans analizi uygulanmıştır. Ortalamalar arasında önemli farklılıkların ortaya çıktığı durumlarda, ortalamaları karşılaştırmak için \% 5 ve \% 1 önemlilik düzeyinde Duncan testi uygulanmıştır. Döl kontrolü parsellerinde; kuru ot verimi, ham protein oranı ve nispi yem değeri ortalamaları bakımından genotiplerin Genel Kombinasyon Yetenekleri belirlenmiştir. Genel Kombinasyon Yeteneği için analizler, SAS (1998) istatistik programında linear karşılaştırma ile Proc MIXED işlemi kullanılarak yapılmıştır. Genel Kombinasyon Yeteneği; bir genotipin ortalama değerinin tüm genotiplerin ortalama değerinden çıkartılarak hesaplanmıştır (Hallauer ve Miranda, 1988).

\section{Bulgular ve Tartışma}

\subsection{Yeşil ot verimi}

Yonca genotipleri arasında istatistiki olarak \%1 düzeyinde farklılık bulunurken, yıllar ve yıl x genotip interaksiyonu arasında $\% \quad 5$ düzeyinde farklılık belirlenmiştir (Çizelge 2).

Çizelge 2. Varyans analiz sonuçları

Table 2. Variance analysis results

\begin{tabular}{lccccccc}
\hline $\begin{array}{l}\text { Varyasyon } \\
\text { kaynakları }\end{array}$ & S.D & $\begin{array}{c}\text { Yeşil ot } \\
\text { verimi }\end{array}$ & $\begin{array}{c}\text { Kuru ot } \\
\text { verimi }\end{array}$ & $\begin{array}{c}\text { Ham } \\
\text { protein }\end{array}$ & ADF & NDF & NYD \\
\hline Tekerrür & 3 & 372051 & 26077 & 2.012 & 0.072 & 0.544 & 7.26 \\
Genotip & 9 & $1744333^{* *}$ & $127060^{* *}$ & 1.645 & $8.174^{* *}$ & $6.786^{*}$ & $228.82^{* *}$ \\
Hata 1 & 27 & 190074 & 10725 & 1.961 & 1.771 & 1.585 & 26.57 \\
Yll & 1 & $1151760^{*}$ & 25266 & $27.824^{* *}$ & $183.01^{* *}$ & $173.93^{* *}$ & $5870.96^{* *}$ \\
Yll x Genotip & 9 & $291327^{*}$ & $21673^{*}$ & 1.741 & 0.694 & 0.897 & 21.11 \\
Hata 2 & 30 & 130354 & 8748 & 1.666 & 1.584 & 2.067 & 44.08 \\
\hline
\end{tabular}

${ }^{*} 0.05,{ }^{* *} 0.01$ düzeyinde önemlidir. 
Yonca genotiplerinde iki yıllık ortalama değerlere göre en yüksek yeşil ot verimi dekara $10319 \mathrm{~kg}$ ile 2 numaralı genotipte belirlenmiştir. 5, 3, 6 ve 1 numaralı genotipler 9536-9213 $\mathrm{kg} \mathrm{da}^{-1}$ ile ikinci gurupta, 7, 9, 4, 10 ve 8 numaralı genotipler ise $8966-8771 \mathrm{~kg} \mathrm{da}^{-1}$ ile üçüncü gurupta yer almışlardır (Çizelge 3). Denemenin yürütüldüğü koşullara benzer ekolojilerde yonca yeşil ot verimlerini; Çöçü ve Sancak (2007) Ankara koşullarında 4532-6695 kg da-1, Mohammed (2008) Ankara koşullarında 7396-8691 kg da ${ }^{-1}$ ve Konya koşullarında 8084-9292 kg da-1, Yılmaz ve Albayrak (2016) Isparta koşullarında 8181-10247 $\mathrm{kg} \mathrm{da}^{-1}$ belirlemişlerdir. Yonca yetiştiriciliğinde iklim, toprak yapısı, gübreleme, sulama imkânları, biçim zamanı, biçim yüksekliği, biçim sayısı, ekolojik koşullar yanında özellikle denemelerde kullanılan çeşit farklılıkları gibi pek çok faktörün birbiriyle etkileşim içerisinde olması yeşil ot verimindeki farklılıkların en önemli sebebi olarak vurgulanmıştır (Gökalp ve ark., 2017).

Çizelge 3. Ortalama yeşil ot ve kuru ot verimleri $\left(\mathrm{kg} \mathrm{da}^{-1}\right)$

Table 3. Average green forage and dry matter yields $\left(\mathrm{kg} \mathrm{da}^{-1}\right)$

\begin{tabular}{lcccccc}
\hline Genotipler & \multicolumn{3}{c}{ Yeșil ot verimi $\left(\mathbf{k g ~ d a}^{-1}\right)$} & \multicolumn{3}{c}{ Kuru ot verimi (kg da-1 } \\
\cline { 2 - 7 } & $\mathbf{2 0 1 6}$ & $\mathbf{2 0 1 7}$ & Ortalama & $\mathbf{2 0 1 6}$ & $\mathbf{2 0 1 7}$ & Ortalama \\
\hline 1. Eğirdir-2 & $9439 \mathrm{~b}$ & $8987 \mathrm{de}$ & $9213 \mathrm{bc}$ & $2377.44 \mathrm{bc}$ & $2331.88 \mathrm{~b}$ & $2354.66 \mathrm{~b}$ \\
2. Yalvaç-3 & $10593 \mathrm{a}$ & $10025 \mathrm{a}$ & $10309 \mathrm{a}$ & $2663.82 \mathrm{a}$ & $2542.44 \mathrm{a}$ & $2603.13 \mathrm{a}$ \\
3. Bolvadin-1 & $9686 \mathrm{~b}$ & $9267 \mathrm{~cd}$ & $9477 \mathrm{~b}$ & $2443.78 \mathrm{~b}$ & $2377.92 \mathrm{~b}$ & $2410.85 \mathrm{~b}$ \\
4. Senirkent-2 & $9070 \mathrm{~b}$ & $8691 \mathrm{e}$ & $8881 \mathrm{c}$ & $2290.86 \mathrm{bc}$ & $2199.76 \mathrm{c}$ & $2245.31 \mathrm{c}$ \\
5. Yeşilova-3 & $9171 \mathrm{~b}$ & $9900 \mathrm{ab}$ & $9536 \mathrm{~b}$ & $2274.58 \mathrm{bc}$ & $2451.74 \mathrm{ab}$ & $2363.16 \mathrm{~b}$ \\
6. Beyşehir-2 & $9372 \mathrm{~b}$ & $9463 \mathrm{bc}$ & $9418 \mathrm{~b}$ & $2301.90 \mathrm{bc}$ & $2431.80 \mathrm{ab}$ & $2366.85 \mathrm{~b}$ \\
7. Çay-1 & $9176 \mathrm{~b}$ & $8755 \mathrm{e}$ & $8966 \mathrm{c}$ & $2287.01 \mathrm{bc}$ & $2188.94 \mathrm{c}$ & $2237.97 \mathrm{c}$ \\
8. Sultandağı-2 & $8948 \mathrm{~b}$ & $8594 \mathrm{e}$ & $8771 \mathrm{c}$ & $2254.32 \mathrm{c}$ & $2138.41 \mathrm{c}$ & $2196.37 \mathrm{c}$ \\
9. Ş.Karaağaç-3 & $9122 \mathrm{~b}$ & $8776 \mathrm{e}$ & $8949 \mathrm{c}$ & $2274.62 \mathrm{bc}$ & $2183.63 \mathrm{c}$ & $2229.13 \mathrm{c}$ \\
10. Y.Badem-1 & $9012 \mathrm{~b}$ & $8733 \mathrm{e}$ & $8872 \mathrm{c}$ & $2219.12 \mathrm{c}$ & $2187.30 \mathrm{c}$ & $2204.11 \mathrm{c}$ \\
Ortalama & $9359 \mathrm{~A}$ & $9119 \mathrm{~B}$ & 9239 & 2338.92 & 2303.38 & 2321.15 \\
VK (\%) & 5.14 & 3.29 & 3.91 & 4.67 & 3.81 & 4.03 \\
\hline
\end{tabular}

*Her bir satır ve sütunda aynı harfler ile gösterilen ortalamalar arasında $\mathrm{P}=0.05$ düzeyinde farklılık yoktur.

\subsection{Kuru ot verimi}

Döl kontrolü parsellerinde yer alan yonca genotiplerininin iki ylllı ortalama kuru ot verimleri ile yapılan varyans analiz sonuçlarına göre; yonca genotipleri arasında istatistiki olarak \%1 düzeyinde farkl1lık bulunurken, y1l $\mathrm{x}$ genotip interaksiyonu arasında \% 5 düzeyinde farklılık belirlenmiştir (Çizelge 2). Yonca genotiplerinde iki yıllık ortalama değerlere göre en yüksek kuru ot verimi dekara $2603.13 \mathrm{~kg}$ ile 2 numaralı genotipte belirlenmiştir. Diğer yonca genotiplerinin kuru ot verimi 2410.85 - $2196.37 \mathrm{~kg} \mathrm{da}^{-1}$ aralığında değişim göstermiştir (Çizelge 3). Kuru ot verimi, çeşit (Avcıoğlu ve ark., 1989; Şengül ve ark., 1992), yaprak/sap oranı (Popovic ve ark., 2001), iklim (Mohammed, 2008), toprak özellikleri (Demiroğlu ve ark., 2008), biçim zamanı (Shroyer ve ark., 1984) vb. birçok faktör tarafından etkilenmektedir. Akdeniz iç geçit kuşağında yoncanın kuru ot verimleri, 1480-1610 $\mathrm{kg} \mathrm{da}^{-1}$ (Albayrak ve Türk., 2013), 2066-2617 kg da ${ }^{-1}$ (Yüksel ve ark., 2016) ve $1791 \mathrm{~kg} \mathrm{da}^{-1}$ (Karayılanlı ve Ayhan, 2014) olarak belirlenmiştir. Araştırmada 2196.37-2603.13 $\mathrm{kg} \mathrm{da}^{-1}$ aralığında belirlenen yonca kuru of verimleri yukarıda adı geçen araştırıcıların bulguları ile uyum içerisindedir.

\subsection{Ham protein oranı}

Döl kontrolü parsellerinde yer alan yonca genotiplerinin ham protein oranları arasında istatistiki olarak farklılık bulunmamakla birlikte, yonca genotiplerin ham protein oranları birinci y1l \% 20.5422.79 , ikinci y1l ise \%20.66-19.67 aralığında değişim göstermişlerdir (Çizelge 4). Kaliteli yonca otunda en uygun ham protein oranı \% 18-24 aralığında olması gerekir (Shewmaker ve ark., 2009). Yoncanın ham protein oranlarını belirlemek için yapılan çalışmalarda; Strbanoviç ve ark. (2017) \% 21.5, Y1lmaz ve Albayrak (2016) \% 18.06, Albayrak ve ark. (2014) \%18.69, Töngel ve Ayan (2010), \% 20.62, Katic ve ark. (2009), $\%$ 17.3, Tucak ve ark. (2008), \% 19.95 oranlarında ham protein belirlenmiştir. Yoncanın erken dönemde biçilmesi ham protein oranının yüksek çıkmasına neden olur. Aşırı yağmurdan dolayı azot kaybı, hasat zamanında yaprakların toprakta kalması ve yabancı ot yoğunluğu gibi faktörler ham protein oranının düşük olmasının nedenlerine örnek olarak verilebilir. Yonca otunun kimyasal kompozisyonunun bölgeye, çeşide, toprak yapısına ve iklim şartlarına, biçim devresi ve kurutma yöntemlerine göre değişiklik gösterdiğini ve biçim geciktikçe ham protein oranının azaldığı bildirilmiştir (Açıkgöz, 2001). 


\subsection{ADF oranı}

ADF oranları bakımından birinci ve ikinci yıllarda yonca genotipleri arasında \% 5 oranında istatistiki olarak farklılık belirlenirken, her iki yılın ortalama ADF oranları ile yıllar arasında ise \%1 oranında farklılık belirlenmiştir (Çizelge, 2). İki yılın ortalama ADF oranlarında $3,7,1$ ve 2 numaralı genotiplerin ADF oranlar1 (sırasıyla, \% 28.42, 28.45, 28.50 ve 29.05) diğer genotiplerin ADF oranlarından daha düşük olarak tespit edilmiştir (Çizelge 4).
ADF oranları SKM oranıyla doğrudan ilişkilidir. Lifler, otun içerisinde en az sindirilebilen kısımları içermektedir. ADF oranının artması SKM oranını azaltmaktadır. Yonca otunun lif içeriğine farklı hasat zamanlarının (Julier ve ark., 2000), olgunlaşma döneminin (Albrecht ve ark., 1987; Lamb ve ark., 2007) farklı lokasyonların (Julier ve Huyghe, 1997) ve yılların (Albrecht ve ark., 1987; Julier ve Huyghe, 1997) etkilerinin olduğu bildirilmektedir. Araştırma bulgularımız yukarıda verilen araştırma sonuçları ile uyum göstermektedir.

Çizelge 4. Ortalama ham protein ve ADF oranları (\%)

Table 4. Average crude protein and ADF ratios (\%)

\begin{tabular}{|c|c|c|c|c|c|c|}
\hline \multirow{2}{*}{ Genotipler } & \multicolumn{3}{|c|}{ Ham protein oranı (\%) } & \multicolumn{3}{|c|}{ ADF oranı (\%) } \\
\hline & 2016 & 2017 & Ortalama & 2016 & 2017 & Ortalama \\
\hline 1. Eğirdir-2 & 22.17 & 20.32 & 21.25 & $27.33 \mathrm{bd}$ & 29.67 c & 28.50 bc \\
\hline 2. Yalvaç-3 & 21.73 & 19.67 & 20.70 & 27.89 ad & $30.21 \mathrm{bc}$ & 29.05 bc \\
\hline 3. Bolvadin-1 & 22.79 & 19.89 & 21.34 & $26.98 \mathrm{~cd}$ & 29.86 bc & 28.42 c \\
\hline 4. Senirkent-2 & 21.12 & 20.98 & 21.05 & 28.45 ac & $31.28 \mathrm{ac}$ & $29.87 \mathrm{ab}$ \\
\hline 5. Yeşilova-3 & 20.91 & 20.76 & 20.84 & $28.13 \mathrm{ad}$ & $31.53 \mathrm{ac}$ & $29.83 a b$ \\
\hline 6. Beyşehir-2 & 20.77 & 20.66 & 20.72 & 28.81 ac & $32.15 \mathrm{ab}$ & 30.48 a \\
\hline 7. Çay-1 & 21.36 & 19.78 & 20.57 & $26.42 \mathrm{~d}$ & $30.48 \mathrm{bc}$ & $28.45 \mathrm{c}$ \\
\hline 8. Sultandağı-2 & 20.54 & 19.29 & 19.92 & $29.19 \mathrm{ab}$ & $31.88 \mathrm{ac}$ & 30.54 a \\
\hline 9. Ş.Karaağaç-3 & 20.83 & 19.81 & 20.32 & $29.13 \mathrm{ab}$ & $32.88 \mathrm{a}$ & $31.01 \mathrm{a}$ \\
\hline 10. Y.Badem-1 & 20.59 & 19.85 & 20.22 & 29.42 a & $32.06 \mathrm{ab}$ & 30.74 a \\
\hline Ortalama & $21.28 \mathrm{~A}$ & $20.10 \mathrm{~B}$ & 20.69 & 28.18 B & $31.20 \mathrm{~A}$ & 29.69 \\
\hline VK (\%) & 8.23 & 4.05 & 6.24 & 4.33 & 4.52 & 4.24 \\
\hline
\end{tabular}

*Her bir satır ve sütunda aynı harfler ile gösterilen ortalamalar arasında $\mathrm{P}=0.05$ düzeyinde farklılık yoktur.

\subsection{NDF oranı}

Yonca genotipleri arasında NDF oranları bakımından ilk yılda \% 5 oranında istatistiki olarak farklılık belirlenirken ikinci yılda farklılık olmamıştır. Her iki yılın ortalama NDF oranlarında ise genotip arasında \% 5, yillar arasında \% 1 önem seviyesinde farklıklar belirlenmiştir (Çizelge 2). İki yılın ortalama NDF oranlarında $1,3,2,7$ ve 4 numaralı genotiplerin NDF oranları (sırasıyla, \% 38.24, 38.48, 38.57, 39.22 ve 39.27) diğer genotiplerin NDF oranlarından daha düşük olarak tespit edilmiştir. Birinci y1l \% 38.07 olan genotiplerin ortalama NDF oranları ikinci y1l \% 41.01'e yükseldiği belirlenmiştir (Çizelge 5). NDF oranları KMT oranlarıyla doğrudan ilişkilidir. Lifler, otun içerisinde en az sindirilebilen kısımları içermektedir. NDF oranının artması KMT oranını azaltmaktadır. NDF oranı ADF oranından daima yüksektir. Çünkü ADF içerisinde selüloz, lignin, silika, kutin ve pektin yer alırken, NDF içerisinde bunlara ilaveten hemiselüloz bulunmaktadır (Cash ve Bowman, 1993). Yoncada NDF oranını; Malushi ve ark. (2017) \% 38.00, Sulc ve ark. (2017) \% 26.7-30.5, Yüksel ve ark. (2016) \% 42.0846.81, Ahmad ve ark. (2016) \% 34.91-44.59, Min (2016) \% 34.9-45.5 olarak belirlemişlerdir. Araştırmamızda elde edilen ortalama NDF oranları bazı araştırıcıların bildirdikleri sonuçlardan yüksek, bazılarınınkinden ise düşük olmuştur. Araştırma bulgularımız yukarda belirtilen araştırmacıların sonuçlarıyla genel olarak benzerlik göstermektedir. Bununla birlikte yoncada kullanılan çeşit ve ekolojik faktörler ile birlikte hasat zamanındaki değişimlerinde otun NDF oranının değişmesinde en etkili faktör olduğu da belirtilmektedir (Rimi ve ark., 2012).

\subsection{Nispi yem değeri}

İki y1lın ortalama NYD incelendiğinde, 1, 3, 2 ve 7 numaralı genotiplerin NYD (sırasıyla, 162.72, 161.74, 160.36 ve 158.96) diğer genotiplerin NYD'den daha yüksek olarak tespit edilmiştir. Birinci yıl 163.89 olan genotiplerin ortalama NYD ikinci yıl 146.76'ya düştüğü belirlenmiştir (Çizelge 5). Kaliteli yonca otunda NYD 120-190 aralığındadır. NYD otun ADF ve NDF oranlarının birlikte değerlendirilmesi ile belirlenmektedir. Dolaysıyla, otun NYD'nin yüksek çıkması için ADF ve NDF oranlarının düşük olması gerekmektedir. Yonca otunun NYD 180'den büyük ise en üstün, 150-180 aralığında üstün, 125-150 iyi, 100120 orta ve 100 'den az ise düşük kaliteli sınıfa girdiği bildirilmektedir (Putman, 2010). Araştırmada, 8 ve 9 numaralı genotipler iyi gurupta yer alırken diğer tüm genotipler üstün gurupta yer almışlardır. 
Çizelge 5. Ortalama NDF ve Nispi yem değeri oranları (\%)

Table 5. Average NDF and Relative feed values (\%)

\begin{tabular}{|c|c|c|c|c|c|c|}
\hline \multirow{2}{*}{ Genotipler } & \multicolumn{3}{|c|}{ NDF oranı (\%) } & \multicolumn{3}{|c|}{ NYD (\%) } \\
\hline & 2016 & 2017 & Ortalama & 2016 & 2017 & Ortalama \\
\hline 1. Eğirdir-2 & $36.53 \mathrm{c}$ & 39.94 & $38.24 \mathrm{~d}$ & $172.21 \mathrm{a}$ & $153.22 \mathrm{a}$ & $162.72 \mathrm{a}$ \\
\hline 2. Yalvaç-3 & $36.98 \mathrm{bc}$ & 40.17 & $38.58 \mathrm{~d}$ & $169.20 \mathrm{ab}$ & $151.37 \mathrm{ab}$ & $160.36 \mathrm{ab}$ \\
\hline 3. Bolvadin-1 & 37.16 bc & 39.78 & $38.47 \mathrm{~d}$ & 169.97 a & 153.49 a & $161.74 \mathrm{a}$ \\
\hline 4. Senirkent-2 & 37.98 aс & 40.55 & 39.27 bd & 163.56 ас & $148.04 \mathrm{ac}$ & 155.81 bc \\
\hline 5. Yeşilova-3 & 38.14 ac & 41.73 & 39.94 ac & $163.61 \mathrm{ac}$ & 143.42 ас & $153.54 \mathrm{~cd}$ \\
\hline 6. Beyşsehir-2 & $38.94 \mathrm{ab}$ & 41.12 & 40.03 ac & $158.84 \mathrm{c}$ & 144.46 ac & $151.98 \mathrm{~cd}$ \\
\hline 7. Çay-1 & 37.55 aс & 40.89 & $39.22 \mathrm{~cd}$ & $169.34 \mathrm{ab}$ & $148.23 \mathrm{ab}$ & $158.96 \mathrm{ab}$ \\
\hline 8. Sultandağı -2 & 39.63 a & 42.13 & $40.88 \mathrm{a}$ & $155.41 \mathrm{c}$ & 141.46 bc & $148.48 \mathrm{~d}$ \\
\hline 9. Ş.Karaağaç-3 & 38.48 aс & 42.56 & $40.52 \mathrm{ab}$ & 160.18 bc & 138.33 c & $149.27 \mathrm{~d}$ \\
\hline 10. Y.Badem-1 & $39.26 \mathrm{a}$ & 41.27 & 40.27 ac & 156.57 c & 144.09 aс & $150.35 \mathrm{~d}$ \\
\hline Ortalama & 38.07 B & $41.01 \mathrm{~A}$ & 39.54 & $163.89 \mathrm{~A}$ & 146.76 B & 155.32 \\
\hline CV (\%) & 3.34 & 3.61 & 3.65 & 3.56 & 4.21 & 4.27 \\
\hline
\end{tabular}

*Her bir satır ve sütunda aynı harfler ile gösterilen ortalamalar arasında $\mathrm{P}=0.05$ düzeyinde farklılık yoktur.

\subsection{Genel kombinasyon yeteneği}

Bitki 1slah programlarında ticari üretim için iyileştirilmiş melezlerin geliştirilmesi en başta gelen amaçlardandır. Genel ve özel uyum yetenekleri, melez kombinasyonlarında saf hatların potansiyel değerini belirten en önemli göstergedir. Özel uyum yeteneği genlerin eklemeli olmayan etkilerine, genel uyum yeteneği ise eklemeli gen etkilerine dayanmaktadır (Turgut ve Duman, 2004). Kombinasyon yeteneği F1 melezinin performansindan melezlerin ortalama performansı çıkarılarak bulunmaktadır (Hallauer ve Miranda 1988).

Toplam kuru ot verimine ait kombinasyon yeteneği değerleri bakımından genotipler arasında istatistiki olarak \% 1 düzeyinde önemli farklar saptanırken, ham protein oranı ve nispi yem değerlerinde ise farklılık bulunmamıştır (Çizelge 6). Toplam kuru ot verimi bakımından 2 ve 3 numaralı genotiplerin kombinasyon yeteneği istatistiki olarak önemli bulunmuştur. 1,5 ve 6 numaralı genotipler ise genel ortalamamadan yüksek kuru ot verimine sahip olmalarına karşın genel kombinasyon yetenekleri istatistiki olarak önemsiz bulunmuştur. Diğer tüm genotiplerin genel kombinasyon yetenekleri ise negatif yönde olmuştur. Ham protein oranı bakımından tüm genotiplerin kombinasyon yetenekleri istatistiki olarak önemsiz bulunmuştur. Buna karşın, 1, 2, 3, 4, 5 ve 6 numaralı genotiplerin genel kombinasyon yetenekleri pozitif yönde olmuştur. Nispi yem değeri bakımından 1, 2, 3 ve 7 numaralı genotiplerin kombinasyon yeteneği istatistiki olarak önemli bulunurken, 4 numaralı genotipin kombinasyon yeteneği pozitif ve istatistiki olarak önemsiz bulunmuştur.

Çizelge 6. Toplam kuru ot verimi, ortalama ham protein oranı ve ortalama nispi yem değerlerine ilişkin genel kombinasyon yeteneği değerleri

Table 6. General combination ability values for total hay yield, average crude protein ratio and average relative feed values

\begin{tabular}{lccc}
\hline Genotipler & Kuru ot verimi $\left(\mathbf{k g ~ d a}^{-1}\right)$ & Ham protein oranı (\%) & Nispi yem değeri \\
\hline 1. Ĕ̆girdir-2 & 33.51 & 0.55 & $7.40^{* *}$ \\
2. Yalvaç-3 & $281.98^{* *}$ & 0.009 & $5.03^{*}$ \\
3. Bolvadin-1 & $89.70^{*}$ & 0.65 & $6.42^{* *}$ \\
4. Senirkent-2 & $-75.84^{*}$ & 0.36 & 0.49 \\
5. Yeşilova-3 & 42.01 & 0.14 & -1.78 \\
6. Beyşehir-2 & 45.69 & 0.02 & -3.34 \\
7. Çay-1 & $-83.18^{*}$ & -0.12 & $3.64^{*}$ \\
8. Sultandağı-2 & $-124.79^{* *}$ & -0.78 & $-6.84^{* *}$ \\
9. Ş.Karaağaç-3 & $-92.03^{*}$ & -0.37 & $-6.04^{* *}$ \\
10. Y.Badem-1 & $-117.05^{* *}$ & -0.47 & $-4.97^{*}$ \\
F & $11.04^{* *}$ & 0.91 & 7.01 \\
SD & 63 & 63 & 63 \\
SH & 35.99 & 0.46 & 1.92 \\
\hline
\end{tabular}

*0.05, ** 0.01 düzeyinde önemli; SD: Serbestlik derecesi SH: Standart hata 
Diğer genotiplerin nispi yem değeri bakımından genel kombinasyon yetenekleri negatif olarak tespit edilmiştir. Yonca 1slahında, sentetik varyete kombinasyonlarında kullanılacak genotiplerin potansiyel değerlerini göstermeleri bakımından genel kombinasyon yeteneklerinin belirlenmesinin çok önemli olduğu bildirilmektedir (Milic ve ark., 2011). Araștırmada, yonca genotiplerinin genel kombinasyon yeteneklerini belirlemek için yapılan test sonucunda; toplam kuru ot verimi bakımından 1, 2, 3, 5 ve 6 numaralı genotipler, yüksek ham protein oranı bakımından 4 numaralı genotip ve yüksek nispi yem değeri bakımından da 7 numaralı genotipin Sentetik-0' oluşturmak amaciyla seçilmesi uygun bulunmuştur.

\section{Sonuç}

Döl kontrolü amaciyla seçilen Eğirdir-2, Yalvaç-3, Bolvadin-1, Senirkent-2, Yeşilova-3, Beyşehir-2, Çay-1, Sultandağı-2, Şarkikaraağaç-3 ve Yenişarbademli-1 yonca (Medicago sativa L.) genotiplerinin ot verimi ile bazı tarımsal karakterleri incelenerek elde edilen sonuçlara göre; Yonca genotiplerinde iki yıllık ortalama değerlere göre en yüksek yeşil ot ve kuru ot verimi dekara $10319 \mathrm{~kg}$ ve $2603.13 \mathrm{~kg}$ ile 2 numaralı genotipte belirlenmiştir. 5, 3, 6 ve 1 numaral genotipler 95369213 kg da-1 yeşil ot ve 2410.85- 2354.66 kg da-1 kuru ot verimi ile ikinci gurupta, 7, 9, 4, 10 ve 8 numaralı genotipler ise 8966-8771 kg da-1 yeşil ot ve 2237.97$2196.37 \mathrm{~kg}$ da-1 kuru ot verimi ile üçüncü gurupta yer almışlardır. Yonca genotipleri arasında 3, 7, 1 ve 2 numaralı genotiplerin ADF oranları (sirasıyla, \% 28.42, $28.45,28.50$ ve 29.05) ve NDF oranlar1 (sirasiyla, $\% 38.48,39.22,38.24$ ve 38.57) diğer genotiplerden daha düşük bulunmuştur. Yonca genotiplerinin ortalama NYD ise 1, 3, 2 ve 7 numaral1 genotiplerin NYD (sirasıyla, 162.72, 161.74, 160.36 ve 158.96) diğer genotiplerin NYD'nden daha yüksek olarak tespit edilmiştir. Yonca genotiplerinin genel kombinasyon yeteneklerini belirlemek amaciyla yapılan test sonuçlarının da birlikte değerlendirilmesi sonucunda; toplam kuru ot verimi bakımından 1 (Eğirdir-2), 2 (Yalvaç-3), 3 (Bolvadin-1), 5 (Yeşilova-3) ve 6 (Beyșehir-2) numaralı genotipler, yüksek ham protein oranı bakımından 4 (Senirkent-2) numaralı genotip ve yüksek nispi yem değeri bakımından da 7 (Çay-1) numaralı genotipin Sentetik-0'1 oluşturmak amaciyla seçilmesi uygun bulunmuştur.

\section{Teşekkür}

$\mathrm{Bu}$ araştırma, Türkiye Bilimsel ve Teknolojik Araştırma Kurumu (TUBİTAK-TOVAG) tarafindan 2140066 proje numarası ile desteklenmiştir.

\section{Kaynaklar}

Açıkgöz, E., 2001. Yem Bitkileri, Uludağ Üniversitesi, Ziraat Fakültesi, Tarla Bitkileri Bölümü, VIPAS Yayın No: 58. 584s. Bursa.

Ahmad, J., Iqbal, A., Ayub, M., Akhtar, J., 2016. Forage yield potential and quality attributes of alfalfa (Medicago sativa L.) under various agromanagement techniques. The Journal of Animal \& Plant Sciences, 26(2): 465-474.

Albayrak, S., Türk, M., Sevimay, C.S., Öten, M., 2018. Türkiye'nin İç ve Sahil Bölgelerine Uygun Yerli Yonca Islahı. TUBITTAK Proje No: 2140066 Sonuç raporu.

Albayrak, S., Türk, M., Sevimay, C.S., Kazaz, S., Tonguç, M., 2014. Göller yöresinde adi yonca (Medicago sativa L.) populasyonlarının toplanmas1 ve karakterizasyon çalışmaları TUBİTAK Proje No: 1100257 Sonuç raporu.

Albayrak, S., Türk, M., 2013. Changes in the forage yield and quality of legume-grass mixtures throughout the vegetation period. Turk J. Agriculture and Forestry. 17(2): 139-147.

Albrecht, K.A., Wedin, W.F., Buxton, D.R., 1987. Cellwall composition and digestibility of alfalfa stems and leaves. Crop Sci. 27: 735-741.

Anonim, 2017. Www. ankom.com. (Erişim tarihi: 15.01.2018)

Avcıoğlu, R., Yıldırım., M.B., Budak, N., 1989. Ege Bölgesine uygun yonca hatlarının geliştirilmesi ve adaptasyonu. E.Ü. Ar. Fonu, 1987-154, İzmir.

Cash, D., Bowman, H.F., 1993. Alfalfa hay quality testing, Montguide, Agriculture, MT-9302.

Çınar, S., Hatiboğlu, R., Gündel, F.D., Aktaş, A., Kılıçalp, N., 2014. Akdeniz iklim kuşağında bazı çok yıllık sıcak mevsim buğdaygil yem bitkilerinin yonca ile karışımlarının performanslarının belirlenmesi, TUBİTAK Proje No: 1100695 Sonuç raporu.

Çöçü, S., Sancak, C., 2007. Bazı yonca çeşitlerinin (Medicago sativa L.) Ankara koşullarında ot verimlerinin belirlenmesi. Türkiye VII. Tarla Bitkileri Kongresi, 25-27 Haziran 2007, Erzurum.

Demiroğlu, G., Geren, H., Avcığlu, R., 2008. Farklı yonca (Medicago sativa L.) genotiplerinin Ege bölgesi koşullarına adaptasyonu. Ege Üniversitesi Ziraat Fakültesi Dergisi. 45(1): 1-10.

Gökalp, S., Yazıcı, L., Çankata, N., İspirli, K., 2017. Bazı yonca (Medicago sativa L.) çeşitlerinin TokatKazova ekolojik koşullarında ot verimi ve kalite performanslarının belirlenmesi. Gaziosmanpaşa Üniversitesi Ziraat Fakültesi Dergisi. 34(3): 114127.

Hallauer, A.R., Miranda, J.B., 1988. Quantitative genetics in maize breeding. Second edition. Iowa State Univ. Press, Ames, IA.

Julier, B., Huyghe, C., Ecalle, C., 2000. Within- and among- cultivar genetic variation in alfalfa forage 
quality, morphology and yield. Crop Sci. 40: 365369.

Julier, B., Huyghe C., 1997. Effect of growth and cultivar on alfalfa digestibility on a multi-site trial. Agronomie 17: 481-489.

Kacar, B., İnal, A., 2008. Bitki Analizleri. Nobel yayınları. No: 1241, Ankara, $892 \mathrm{~s}$.

Karayllanl1, E., Ayhan, V., 2016. Investigation of feed value of alfalfa (Medicago sativa L.) harvested at different maturity stages. Legume Research. 39(2): 237-247.

Katiç, S., Miliç, D., Karagiç, Đ., Vasiljeviç, S., Glamociç, D., Jajiç, I., 2009. Variation of protein, cellulose and mineral content of lucerne as influenced by cultivar and cut. Biotechnology in Animal Husbandry. 25(5-6): 1189-1188.

Lamb, J.F.S., Jung, H.J.G., Sheaffer, C.C., Samac, D.A., 2007. Alfalfa leaf protein and stem carbohydrate and lignin content under hay and biomass management systems. Crop Sci. 47: 1407-1415.

Malushi, N., Papa, L., Maia, M., Oliveira, H., 2017. Determination of chemical content and dry matter digestibility of some under-utilized feeds in ruminants feeding through two in vitro methods. Scientific Papers. Series D. Animal Science. Vol. LX: 91-96.

Miliç, D., Mihailoviç., V. Karagiç., D. Vasiljeviç., S. Mikiç., A. Katiç. S. 2011. Efficacy of progeny tests in alfalfa (Medicago sativa L.) breeding for yield and quality. Field Veg. Crop Res. 48: 327-332.

Min, D., 2016. Effects of cutting interval between harvests on dry matter yield and nutritive value in alfalfa. American Journal of Plant Sciences. 7: 12261231.

Mohammed, A.S., 2008. Farklı lokasyonlarda bazı yonca çeşitlerinin yem verimleri ve bitkisel özellikleri. Ankara Üniversitesi Fen Bilimleri Enstitüsü Tarla Bitkileri Anabilim Dalı Yüksek Lisans Tezi, Ankara.

Putman, D., 2010. Changing forage quality testing for alfalfa hay markets, California Alfalfa \& Forage Symposium, Visalia, CA, Nov. 30-Dec 2, 2010, USA.

Popovic, S., Stjepanovic, M., Grljusic, S., Cupic, T., Tucak, M., 2001. Protein and fiber contents in alfalfa leaves and stems. Centre International de Hautes Etudes Agronomiques Mediterraneennes.

Radoviç, J., Sokoloviç, D., Markoviç, J., 2009. Alfalfamost important perennial forage legume in animal husbandry. Biotechnology in Animal Husbandry. 25: 465-475.

Poehlman, J.M., Sleper, D.A., 1995. Breeding Field Crops. 4th edn. Iowa State Univ. Press, Ames.

Riday, H., Brummer, E.C., 2002. Forage yield heterosis in alfalfa. Crop Sci. 42: 716-223.
Rimi, F., Macolino, S., Leinauer, B., Lauriault, L.M., Ziliotto, U., 2012. Fall dormancy and harvest stage effects on alfalfa nutritive value in a subtropical climate. Agron. J. 104: 415-422.

SAS Institute. 1998. INC SAS/STAT users' guide release 7.0, Cary, NC, USA.

Shewmaker, G.E., Chahine, M., Wilson, R., 2009. Parameters for good quality alfalfa hay. Idaho Alfalfa Forage and Forage Conferance, 3-4 February, 6-10. USA.

Shroyer, J., Fjell, D., Mikesell, M., 1984. Timely cutting of alfalfa. Kansas State Universty Cooperative Extension Service.

Strbanoviç, R., Stanisavljevica, R., Dukanovica, L., Postica, D., Markovicb, J., Gavrilovica, V., Dolovaca, N., 2017. Variability and correlation of yield and forage quality in alfalfa varieties of different origin. Tarım Bilimleri Dergisi. 23: 128137.

Sulc, R.M., Parker, A., Albrecht, K., Cassida, K., Hall, M., Min, D., Orloff, S., Xu, X., Undersander, D., 2017. Agronomic and nutritional attributes of reduced lignin alfalfa, Tri-State Nurtition Conference. April 17-19; 79-87.

Şengül, S., Tahtacioğlu, L., Mermer, A., 1992. Doğu Anadolu Bölgesi şartlarına adapte olabilecek yüksek verimli yonca çeşit ve hatlarının belirlenmesi üzerine bir araştırma. Doğu Anadolu Tarimsal Araştırma Enstitüsü Müdürlüğü Yayınları No: 15, Erzurum.

Töngel, M.Ö., Ayan, İ., 2010. Nutritional contenst and yield performances of lucerne (Medicago sativa L.) cultivars in Southern Black Sea Shores, Journal of Animal and Veterinary Advances. 9: 2067-2073.

Tucak, M., Popovic, S., Bolaric, S., Kozumplik, V., 2008. Agronomic evaluation of alfalfa genotypes under ecological comditions of Eastern Croatia. VII. Alps-Adria Scientific Workshop, Cereal Research Communications, supp1., vol. 36, 651- 654. Stara Lesna, Slovakia.

Turgut, İ., Duman, A., 2004. Misirda (Zea mays indentata Sturt.) kombinasyon yeteneği ve melez gücü üzerine araştırmalar. Uludağ Üniv. Zir. Fak. Derg. 18(1): 129-143.

Y1lmaz, M., Albayrak, S., 2016. Isparta ekolojik koşullarında bazı yonca (Medicago sativa L.) çeşitlerinin ot verim ve kalitelerinin belirlenmesi. Tarla Bitkileri Merkez Araştırma Enstitüsü Dergisi. 25(1): 42-47.

Yüksel, O., Albayrak, S., Türk, M., Sevimay, C.S., 2016. Dry natter yields and some quality features of alfalfa (Medicago sativa L.) cultivars under two different locations of Turkey. Süleyman Demirel Üniversitesi Fen Bilimleri Enstitüsü Dergisi. 20(2): 155-160. 